\title{
OS POPULISMOS DE FRANCISCO WEFFORT
}

\section{Daniela Mussi}

(D) https://orcid.org/0000-0002-5845-0317

\section{André Kaysel Velasco e Cruz ${ }_{(2)}$}

\author{
(D) https://orcid.org/0000-0003-2467-5363 \\ (1) Professora colaboradora do Departamento de Ciência Política da Universidade de São Paulo (USP), São Paulo - SP, Brasil. E-mail: danixhm@usp.br \\ (2) Professor do Departamento de Ciência Política da Universidade Estadual de Campinas (Unicamp), Campinas - SP, Brasil. E-mail: andre.kaysel@gmail.com
}

DOI: $10.1590 / 3510409 / 2020$

\section{Introdução}

Entre setembro de 1963 e meados de 1971 o cientista político Francisco Weffort escreveu e publicou um conjunto de textos sobre o populismo no Brasil. Algum tempo mais tarde, em 1978, reuniu parte deste material em um livro intitulado $O$ populismo na politica brasileira. A coletânea celebrizou as ideias do autor sobre o populismo, fazendo com que a distância temporal de 15 anos entre o primeiro artigo e a publicação da mesma fosse, em grande medida, desprezada pelos intérpretes de seu pensamento. ${ }^{1}$ Para suprimir esta lacuna na literatura sobre o populismo no pensamento político brasileiro, o presente artigo reconstrói o percurso dos textos de Weffort em seu contexto, bem como explora as revisões de escrita das partes que viriam a compor a coletânea de $1978 .^{2}$

Artigo recebido em: 05/02/2019

Aprovado em: 22/01/2020
Entre 1963 e 1968, Weffort foi pós-graduando na Universidade de São Paulo (USP), período marcado pela ascensão da crítica ao nacionalismo e ao comunismo soviético entre os intelectuais de esquerda. Como jovem cientista social uspiano, participou, entre 1963-1964, de um projeto coletivo no Centro de Estudos Industriais e do Trabalho (Cesit), coordenado por Gabriel Cohn, que resultou no livro Politica e revolução social no Brasil, publicado em 1965. Para este, Weffort contribuiu com o capítulo "Política e massas", no qual analisou criticamente as ambiçóes e impasses da política nacionalista no contexto brasileiro. Foi quando redigiu, também, as primeiras conclusôes da pesquisa empírica que conduzia a respeito das "raízes do populismo" nas eleiçôes municipais em São Paulo. Assim começou sua trajetória de estudos do populismo.

Em seguida, depois do golpe militar de 1964, escreveu "Estado e massas no Brasil", artigo em que analisou o populismo como fenômeno interno à 
dinâmica de formação e autonomização do Estado brasileiro em relação às classes sociais. Nesse período, o argumento de Weffort funcionava como crítica “interna” a uma hegemonia intelectual e cultural nacionalista. Para tal, propunha que o populismo não poderia ser interpretado como uma forma política pré-ideológica - tal como pensavam os intelectuais do Instituto de Superior de Estudos Brasileiros (Iseb) -, mas deveria ser considerado como comportamento político no sentido pleno da palavra e, apenas assim, tomado como ponto de partida possível para a resistência contra o conservadorismo emergente.

Em 1967, trabalhando como pesquisador no Instituto Latino-Americano de Pesquisas e Estudos Sociais (Ilpes), ${ }^{3}$ no Chile, Weffort se aproximou de intelectuais preocupados com o problema da relação entre desenvolvimento e dependência na América Latina e no Brasil. Neste ano, publicou o artigo $O$ populismo na politica brasileira e, em seguida, finalizou sua tese de doutorado, Classes populares e politica: contribuição ao estudo do populismo, defendida em abril de 1968 na USP. Nestes textos, o nacionalismo aparece "conjugado no passado", e a análise do populismo como política de "transição" passa a ser pensada nos limites intransponíveis da política nacional-burguesa que a nascente teoria da dependência sinalizava.

Em seguida, impactado pelas mobilizaçóes estudantis e operárias de 1968, no Brasil e no mundo, Weffort procurou afastamento definitivo tanto da perspectiva nacionalista (e comunista) como das análises cepalinas e da dependência sobre o populismo. Pesquisador do recém-fundado Centro Brasileiro de Análise e Planejamento (Cebrap), Weffort avançou a ideia de que apenas uma nova "teoria de classe" independente seria capaz de oferecer as ferramentas para análise do fenômeno na América Latina. Foi nesse contexto, aliás, que escreveu Notas sobre a 'teoria $d a$ dependência': teoria de classe ou ideologia nacional como síntese de suas posiçóes no momento. Os escritos do período mencionado, como veremos, foram os que Weffort organizou em $O$ populismo na politica brasileira. Publicada em 1978, contudo, essa obra deixou de fora toda a pesquisa conduzida depois de 1978 sobre o populismo, mais precisamente sobre o sindicalismo populista.
O presente artigo recupera, portanto, o percurso que separa a redação dos primeiros artigos sobre o populismo no início dos anos 1960 da publicação da coletânea de 1978. Para tal, vale-se de recursos filológicos de pesquisa, ou seja, da análise das diferentes versóes dos escritos de Weffort, bem como da conexão específica entre os documentos estudados e o ambiente intelectual no qual o autor se insere, como forma de reconstruir o desenvolvimento de seu pensamento político. ${ }^{4}$ Como resultado, propóe que: a) na coletânea de 1978 estão presentes ao menos dois sentidos do conceito de populismo, anteriores a 1971 ; b) consequentemente, Opopulismo na politica brasileira não contempla uma definição homogênea ou finalizada do conceito, já que deixa de fora o conceito de sindicalismo populista, com o qual Weffort trabalhou ao longo de toda a década de 1970. Por fim, conclui que, para uma crítica rigorosa do conceito de populismo em Weffort, é importante levar em conta a leitura cronologicamente informada da coletânea, bem como o estudo dos textos deixados de fora da mesma.

\section{O populismo como fenômeno eleitoral}

A pesquisa sobre o populismo levada a cabo por Weffort nasceu em um ambiente intelectual marcado pela emergência da "sociologia aplicada" na USP ao longo dos anos 1950. Aflorava, então, entre os intelectuais uspianos, a necessidade de edificar uma contribuição específica para o debate público nacional capaz de reagir à hegemonia intelectual nacionalista conquistada pelo Iseb (cf. Romão, 2006, pp. 25-29, pp. 171-172; Schwarz, 1999; Rodrigues, 2012). ${ }^{5}$ No início dos anos 1960, esse ambiente intelectual se tornaria mais efervescente quando os temas do desenvolvimento econômico entraram em conflito cotidiano com as reflexóes sobre o desenvolvimento político, especialmente aquela a respeito da transformação social possibilitada pela urbanização e industrialização.

O Cesit, fundado por Florestan Fernandes em 1961, vinculava-se diretamente a este novo momento e tinha como eixos de pesquisa justamente o estudo das características da indústria brasileira, do papel do Estado em sua estruturação e das "mentalidades" 
sociais a ela relacionadas, tanto a empresarial como a operária (Romão, 2006, pp. 27-28). Nessa agenda, o nacionalismo figurava como objeto amplo de análise, como amálgama ou substrato das mudanças por meio das quais o país poderia deixar para trás o subdesenvolvimento.

Foi nesse ambiente de efervescência política nacional e sob a cultura universitária de forte viés cientificista em São Paulo que Francisco Weffort deu os primeiros passos como intelectual (Romão, 2006, p. 36, p. 57; cf. Vianna, 1994). Weffort era "aprendiz" de uma ciência sociológica em luta contra o subdesenvolvimento e o tradicionalismo cultural do país, inserida, portanto, em um paradigma modernizante e universalizante do conhecimento e da ação. Nesse sentido, é completamente coerente com este ambiente encontrar, em seu primeiro artigo sobre o populismo, escrito em 1963, como ponto de partida - ainda que crítico - as ideias de intelectuais nacionalistas isebianos (Romão, 2006, p. 62; Bariani, 2003).

Política de massas, a primeira intervenção de Weffort sobre o conceito, fez parte do livro coletivo realizado no Cesit, Politica e revolução social no Brasil, organizado por Octavio Ianni com artigos, ainda, de Paul Singer e Gabriel Cohn, todos escritos no segundo semestre de 1963 e revisados para publicação em 1965. Planejado e realizado imediatamente antes do golpe militar de 1964, o livro foi concebido a partir de "um programa comum" com vistas "a apontar as orientaçōes fundamentais da atividade política" diante "das profundas e rápidas transformaçôes em curso", em um cenário de "crises e desequilíbrios econômicos e políticos" (Ianni, 1965, p. 9). Os capítulos, por sua vez, obedeceram a uma estrutura composta por uma introdução seguida da divisão do texto em subitens enumerados. Ianni escreveu sobre Processo politico e desenvolvimento econômico, Singer sobre A política das classes dominantes, Cohn sobre as Perspectivas da esquerda, e coube a Weffort o tema da Politica de massas. Nessa divisão temática, a política das organizaçôes de esquerda está separada da política "de massas", o que sugere que populismo não se referia apenas à política das organizaçôes de esquerda. ${ }^{6}$

O capítulo de Weffort, escrito em setembro de $19633^{7}$ discutiu o caráter de "parceiro-fantasma" da participação das massas populares na política brasileira depois de 1930. Mesmo em 1963, entre reformistas e conservadores polarizados em torno do sentido das "reformas de base" depois da renúncia de Jânio Quadros, o padrão se mantinha: elogio genérico da participaçáo do povo na política combinado à reflexão sistemática sobre como evitar seus efeitos, o que conduzia o jogo político a sucessivos impasses (cf. Toledo, 2004). O populismo seria um momento de crise das modalidades "tradicionais" de atuação das elites políticas e, por isso, de abertura para novas possibilidades de participação popular. Em contextos de crise, a "impotência política dos grupos dominantes permite vislumbrar grandes transformações na estrutura de poder [...]" (Weffort, 1965a, p. 163). ${ }^{8}$

Para Weffort, a entrada das massas na política brasileira resultava da confluência de dois processos históricos, um econômico e outro político: o primeiro, mais longo no tempo, era efeito da combinação entre estagnação da estrutura agrária e desenvolvimento urbano-industrial depois de 1930; o segundo, conjuntural, seria o processo de crise desencadeado pela democratização de 1945. Desse modo, o início dos anos 1960 seria marcado pela sincronia entre crise econômica e crise política e o regime político democrático estaria diante da clássica "tarefa trágica": a da possível subversão da incorporação das camadas populares ao processo político em uma revolução social (Weffort, 1965a, p. 164).?

Como o populismo se encaixava nessa narrativa? $\mathrm{Na}$ interpretação de Weffort, a democratização de 1945 teria criado, com a ampliação do sufrágio e o alistamento ex oficio, as condiçôes institucionais para que as camadas populares exercessem, por meio do voto, uma pressáo efetiva, com "certa autonomia", embora limitada e indireta, sobre as relaçóes de força das elites econômicas e políticas, contribuindo inclusive para sua renovação (Weffort, 1965a, p. 164). Apesar disso, a participação popular permanecia fundamentalmente distante dos partidos e associaçóes tradicionais como sindicatos e entidades estudantis (Weffort, 1965a, p. 167). ${ }^{10}$ Em um cenário de "incapacidade de penetração popular dos partidos" e associações, a participação das massas na política democrática se realizava como relação direta entre eleitores e candidatos. 
Apesar do caráter atomizado dessa relação, o simples fato de que os eleitos devessem prestar contas, ainda que simbolicamente, aos seus eleitores teria introduzido uma mudança qualitativa em comparação com a política oligárquica da República Velha. A popularização da política eleitoral, aliás, era o que fomentava a insatisfação de parte das classes médias tradicionais com a democratização, a qual viam como degradação moral da vida pública; uma "repulsa que náo pode esconder a nostalgia dos tempos da 'República Velha”" (Ibid., p. 169). Para Weffort, portanto, o desenvolvimento da democracia brasileira se dava tanto no enfrentamento da crise crescente de composição política entre os grupos dominantes como em reaçáo à emergência periódica de políticos demagogos. Esse processo, por sua vez, produzia uma situação paradoxal que Weffort denominou por "fascínio do Estado". Neste, convergiam tanto "a liderança populista que se constitui na raiz do poder real", como "o nacionalismo que inspira a expressão organizada das massas” sem organizá-la de fato (Ibid., p. 171). ${ }^{11}$

Nesse sentido, ao definir o conceito de populismo como "manifestação [eleitoral] de uma situação de classes”, Weffort (1965b, p. 54) voltou sua crítica para os intelectuais liberais elitistas e para os nacionalistas com vistas a desmascarar conteúdo "ideológico" das duas visóes (Romão, 2006, p. 54ss; Fernandes, 1976). O populismo não poderia ser reduzido a uma relação carismática, mas seria a expressão política das dificuldades das classes sociais em ir além da "tradição". Caberia aos seus intérpretes, portanto, não compactuar com esse viés ideológico, mas contribuir para "ajustar" em termos científicos a "percepção" dos "homens de ação" para a realidade da política brasileira (Weffort, 1965b, p. 81).

Apesar da crítica ao senso comum ideológico, contudo, Weffort buscou se afastar da interpretação elitista que via o populismo como pura demagogia e adulação da massa popular pelo líder personalista desprovido de programas ou ideias. ${ }^{12}$ Para tal, apontou certo elitismo na própria interpretação nacionalista que, apesar da afinidade aparente com o povo, aproximava-se do diagnóstico de seus adversários ao caracterizar o populismo como fenômeno pré-ideológico ou a-ideológico. O esforço por se afastar tanto do liberalismo demofóbico das elites tradicionais paulistas como do nacionalismo paternalista das elites cariocas o levou a uma interpretação distinta da participação eleitoral das classes populares.

$\mathrm{Na}$ primeira análise de Weffort da crise que antecedeu o golpe de 1964, o populismo aparece descrito como uma forma concreta de "participação popular" expressa na formação de uma "liderança populista que se constitui na raiz do poder real" (Weffort, 1965a, p. 171). Essa definição era resultado da absorção parcial da interpretação oferecida por Hélio Jaguaribe para o fenômeno ${ }^{13}$ (Ibid., p. 174). Ao analisar o "voto adhemarista" nas eleições em Sáo Paulo nos anos 1950, Jaguaribe notara que este se distinguia dos tipos de comportamento eleitoral tradicionais, o voto "clientelista" e o voto "ideológico" ${ }^{14} \mathrm{O}$ primeiro era visto como típico das máquinas eleitorais rurais, clientelistas, e o segundo como característico voto urbano, organizado em bases classistas (Jaguaribe, 1954, p. 141). Embora Adhemar de Barros e a máquina do Partido Social Progressista (PSP) lançassem mão de estratégias clientelistas, Jaguaribe notava que a adesão do eleitor rural ao partido não se dava pela lógica clientelista, mas sim pela figura carismática do candidato. Do mesmo modo, notava que os trabalhadores urbanos e os pequenos burgueses que votavam em Adhemar de Barros não o faziam por motivos ideológicos, mas igualmente pelo vínculo personalista.

Para explicar esse curioso padrão, Jaguaribe propunha entender o adhemarismo como um fenômeno típico de sociedades de massa: por um lado, as classes dominantes não possuíam capacidade dirigente, perdendo a ascendência política sobre os grupos subalternos; por outro, as classes trabalhadoras tampouco eram capazes de uma consciência política autônoma adequada à sua situação (Jaguaribe, 1954, pp. 144-145). Nessa conjunção crítica, os grupos sociais eram dispersados em uma "situação de massa", ou seja, uma situação na qual os indivíduos se encontravam isolados em um todo amorfo. A constituição da sociedade de massa, por sua vez, seria o terreno propício para a emergência de lideranças personalistas, carismáticas, que apelam ao homem-massa atomizado. Esse tipo de vínculo político é o que Jaguaribe chamaria por populista (Jaguaribe, 1954, p. 146). 
Para Guerreiro Ramos, a ascensão ao poder de um candidato desvinculado dos principais partidos políticos e com inclinaçóes bonapartistas representava a crise do conjunto do sistema partidário, incapaz de canalizar as contradiçóes econômicas e sociais cada vez mais agudas da sociedade brasileira (Ramos, 1961, pp. 21-22). O populismo representaria um fenômeno da fase inicial da industrialização da sociedade brasileira, quando as classes trabalhadoras começavam a se constituir, mas ainda não possuíam consciência de classe (Ramos, 1961, pp. 56-57). Para Weffort, porém, o populismo não poderia ser tomado como constatação da ausência de consciência política, mas sim como um "fenômeno político no sentido pleno da expressão". Além disso, sendo um fenômeno urbano, apesar da aparente "atomização" da relação entre candidato-eleitor, o populismo não poderia ser equiparado a uma "relação de dominação entre indivíduos" (Weffort, 1965a, p. 175; 1965b, p. 54). ${ }^{15}$

Assim, ao rejeitar a caracterização do populismo como fenômeno pré-ideológico ou individualizado, Weffort mirava especialmente o que considerava como inconsistências analíticas da abordagem nacionalista (Weffort, 1965a, p. 173). Essa operação tinha um claro propósito: confrontar a "pressão ideologizante" $16 \mathrm{da}$ interpretação nacionalista nas análises das esquerdas no contexto de polarização política que se aprofundava no início dos anos 1960. Desde a importante Declaração sobre a politica do PCB, publicada em março de 1958 no $A$ Voz Operária, o Partido Comunista Brasileiro (PCB) orientava sua ação por uma "nova política", marcada pela ideia de composiçáo de uma "frente única” democrática e nacionalista (Segatto, 1995). O PCB entendia que, ao "impulsionar o movimento nacionalista, ampliar seu caráter de massas e ajudar sua coordenação em escala nacional", seria possível "acelerar a polarização em processo" (Comitê Central do PCB, 1958/1982, p. 187). O partido, assim, pretendia realizar uma "abertura para a sociedade" e passava a defender um "caminho pacífico para o socialismo" (Ferreira, 2013, p. 115).

Essa postura levava, na opiniáo de Weffort, o PCB a assimilar de maneira mecânica a política populista e os grupos sociais a ela ligados, e defendê-la como etapa necessária para o enfrentamento do “imperialismo norte-americano". ${ }^{17}$ Para Weffort, essa "pressão ideológica” nacionalista em defesa do populismo conduzia a um paradoxo, pois ao mesmo tempo em que os nacionalistas buscavam se aproximar do povo, eram incapazes de superar um horizonte tradicional elitista de análise da política, mais coerente ao pensamento liberal "decadente" e sua atitude reacionária diante da participação política popular. Assim, para intervir nesse terreno ideológico em que o nacionalismo predominava, Weffort procurou oferecer outra interpretação do populismo, que o afastasse de ideias como "ausência de ideologia", "demagogia", "apelo emocional" e "paternalismo" e pudesse levantar dúvidas sobre a estratégia do impulso do nacionalismo como movimento político (Weffort, 1965b, p. 172). Apresentou, então, a seguinte definição: "O populismo é, no essencial, a exaltação do poder do Estado, é o próprio Estado se colocando, através do líder, em contato direto com os indivíduos reunidos na massa" (Weffort, 1965a, p. 176). ${ }^{18}$

Com base nesta definição, Weffort propôs pensar o populismo a partir de duas formas de liderança política: espontânea e consciente. Como exemplos do desenvolvimento do populismo em sua "forma espontânea", identificou os casos do "adhemarismo" e o "jainismo" tomando como base os resultados preliminares de uma pesquisa sobre as eleições estaduais de São Paulo em 1962. O texto resultante dessa análise, também escrito em 1963, foi publicado em artigo na recém-fundada Revista Civilização Brasileira (RCB), ${ }^{19}$ em 1965, sob o título de Raizes sociais do populismo em Sáo Paulo. ${ }^{20}$ Neste, o autor constatou que Jânio Quadros obtivera maior votação nas cidades paulistas de expressiva concentração urbano-industrial ${ }^{21}$ - saindo-se vitorioso na capital - enquanto Adhemar de Barros ganhara a eleição, em grande medida, devido ao maior número de votos recebido nas pequenas cidades do interior (Weffort, 1965b, pp. 49-50). Ao desagregar os dados referentes à distribuição dos eleitores entrevistados por grupo social de cada candidato, mostrou que a categoria "massa, entendida como conjunto amorfo e indiferenciado" não era suficiente para entender o fenômeno populista (Weffort, 1965b , p. 52).

Entre os trabalhadores não operários, os dados mostraram o desempenho de Jânio melhor entre os 
assalariados de escritório, mas Adhemar se saía melhor entre assalariados de serviços de baixa remuneração, como empregados domésticos, porteiros e balconistas do comércio. Weffort concluiu, então, que o janismo possuía sua base e apoio entre os trabalhadores de melhor renda per capita, ao passo que o adhemarismo se enraizava entre os trabalhadores mais empobrecidos e de baixa qualificação profissional, entre os quais os trabalhadores do setor de serviço e também o operariado (Weffort, 1965b, pp. 52-53). As distintas bases sociais correspondiam, portanto, a diferentes perfis ideológicos, formas mais ou menos espontâneas de expressão de interesses político que os dois candidatos populistas haviam sido capazes de captar e mobilizar eleitoralmente.

$\mathrm{O}$ artigo reverberou a argumentação presente no texto mais geral, preparado para o livro do Cesit de valorização do populismo, como não restrito a uma noção mecânica de consciência de classe, podendo incorporar não apenas os setores médios, como normalmente se supunha, como também grupos sociais assalariados, e mesmo o operariado urbano, como no caso do janismo, cujo moralismo popular teria a função de cobertura ideológica, uma inclinação à política reformista bastante difundida entre os operários (Weffort, 1965a, p. 185).

Apesar das diferenças, Weffort notava que as duas formas de populismo levavam a "uma traição à massa popular" pelas lideranças eleitorais e a uma crise da democracia "que conduzirá, sempre à superação da pequena burguesia, seja através da revolução, seja através do desenvolvimento capitalista e do esmagamento do pequeno burguês pelos grandes capitais" (Weffort, 1965a, pp. 182-183). ${ }^{22}$ Se adhemarismo e janismo eram expressóes espontâneas do populismo, continuou, o nacionalismo poderia ser considerado uma forma "consciente" desse mesmo fenômeno, "mais radical", feita sempre "em nome do povo" apesar de jamais conseguir superar a própria marginalidade (Weffort, 1965b, p. 187). Apesar de conceber o populismo como fenômeno pré-ideológico, na prática o nacionalismo o convertia em uma ideologia política por meio de um conceito mistificado de nação e de unidade nacional. ${ }^{23}$ Isso fazia do nacionalismo uma forma "ideológica" de populismo, uma espécie de consciência populista, ou seja, uma consciência justificadora da "traição" das classes trabalhadoras por lideranças e representantes.

Em suas primeiras análises do populismo, portanto, Weffort enfrentava a conjuntura política no contexto da crise democrática de 1963-1964. Sua interpretação da potencialidade política "à esquerda" do populismo, nesse cenário, combinava-se à crítica daquela que considerava ser a "ideologia dominante" entre as forças populares. O nacionalismo era "a concepção política que mais influência tem alcançado ao pretender dar resposta a todos os problemas brasileiros", ao mesmo tempo em que se mostrava fundamentalmente incapaz de enfrentar os desafios colocados pelo golpe militar (Weffort, 1965b, p. 188). $\mathrm{Na}$ preparação da nova versão do texto para a coletânea O populismo na politica brasileira, o nacionalismo seria apresentado como "ideologia de substituição num período de evidente crise de hegemonia das classes dominantes", e as expectativas contidas nas análises de 1963, removidas. Em 1978, as dúvidas e potencialidades do nacionalismo seriam substituídas pela argumentação de que "os nacionalistas nunca se propuseram, nem o poderiam representar o povo atual, concreto e contraditório" dada sua "prática orientada pela busca constante do compromisso e pela preocupaçáo de evitar a todo o custo situaçóes de conflito" (Weffort, 1978a, pp. 37-38).

\section{O populismo como compromisso estatal dependente}

Entre abril de 1964 e maio de 1965, Weffort escreveu um novo artigo sobre o populismo, Estado e massas no Brasil, que seria publicado em maio de 1966 na mesma $R C B .{ }^{24}$ A noção de "compromisso" reapareceu no centro deste que foi o primeiro artigo sobre o populismo escrito depois da derrubada de João Goulart pelos militares e a derrota da esquerda nacionalista e democrática, em abril de 1964. Na coletânea de 1978, Estado e massas no Brasil seria reorganizado como Capítulo II da Primeira Parte, logo em seguida ao Capítulo I, Política de Massas.

Nesse texto pós-golpe, Weffort avançou a ideia de superar a "acentuada intenção normativa" da interpretação nacionalista sobre o populismo e identificar o próprio nacionalismo como uma 
ideologia populista (Weffort, 1966, p. 138n). Para tal, procurou localizar de maneira mais precisa o momento de ascensão da ideologia nacionalista no governo Juscelino Kubitschek, com sua função de "cobertura ideológica do 'desenvolvimento", de aparência que confere coerência a um "quadro geral" "de consagração do Estado", bem como seu esforço de "transfiguração teórica do populismo" como maneira de ocultar a si mesma como ideologia populista (Weffort, 1966, p. 147). O nacionalismo passava, agora, a ser apresentado como objeto de pesquisa, em contraste com os textos de 1963 em que aparecia como "adversário" político. Weffort passaria a se referir ao nacionalismo sempre no passado.

Outra "novidade" desse artigo foi a incorporação de algumas fontes bibliográficas diferentes para o tratamento conceitual do populismo. Foi o caso, por exemplo, do livro Politica y masas en una época de transición (1962), do sociólogo argentino Gino Germani, de onde Weffort retirou a ideia da transição de uma "democracia com participação limitada" para uma democracia "de participação ampliada", para se referir à passagem da República Velha para o período pós-Revolução de 1930 (Weffort, 1966, pp. 137-138). Além disso, para a crítica das ideias econômicas nacionalistas, incorporou os textos de Celso Furtado, Dialética do desenvolvimento (1964), Fernando Henrique Cardoso, Empresário industriale desenvolvimento econômico (1964) e Alain Touraine, Industrialization et Conscience Ouvrière a São Paulo (1961) (Weffort, 1966, p. 138, 2n).

De Furtado, Weffort reteve a noção de "condicionantes estruturais" que precedem, orientam e explicam a entrada das massas brasileiras na vida estatal capitalista, assim como sua crise. Furtado, nesse texto, reconhecia a ideologia nacionalista como a única "capaz de integrar em sua plenitude os interesses antagônicos de classes", devido ao peso da formação e defesa do mercado nacional no desenvolvimento do capitalismo industrial brasileiro (Furtado, 1964, p. 69). Por outro lado, dada sua natureza subdesenvolvida, reconhecia que a expansão do regime democrático no capitalismo brasileiro exigiria necessariamente uma maior "incorporaçáo" ao processo político de "grupos econômicos e sociais de maior relevância" com vistas a equacionar o aumento de tensóes sociais e o recurso a "soluçóes extralegais" por setores das classes dirigentes para solução das mesmas (Furtado, 1964, p. 73).

Esta seria, para Furtado, a contradição-chave da política nos países subdesenvolvidos, ou seja, a dificuldade "endógena" de conformação de uma "consciência de classe na massa trabalhadora industrial", com a consequente adesão desta a "ideologias da classe dominante", "conhecidas sob a forma genérica de populismo" (Furtado, 1964, p. 77). Para Furtado, então, a política populista poderia servir como meio para avanço das classes populares em um confronto contra a burocratização e massificação do Estado, ou seja, contra a "incorporação definitiva na estrutura social do sistema de privilégios defendido pela classe dirigente, $[\ldots]$ considerados como dado a priori numa escala de valores incontestada" (Furtado, 1964, p. 77). O economista não deixava de notar, contudo, a debilidade do populismo enquanto política de promoçâo de uma "efetiva participação" das massas assalariadas e camponesas "no processo de formação do poder" (Furtado, 1964, p. 90). O populismo, ao contrário, favorecia "golpes de mão" por setores das classes dirigentes sempre que se sentissem ameaçados e/ou perdendo o controle da "massa de manobra" popular (Furtado, 1964, p. 86).

Inspirado pelas ideias de Furtado, Weffort reafirmou a necessidade de pensar "a condição de marginalidade e de dependência econômicas do processo de industrialização em relação à estrutura agrária tradicional" (Weffort, 1966, p. 139). O uso do termo "dependência", com base em Furtado, servia para indicar o "processo de industrialização [que] aparece limitado pelas estruturas tradicionais" (Weffort, 1966, p. 139, 3n). A noção de dependência estrutural, aqui, permitia a Weffort deslocar sua interpretação do populismo para uma linguagem de tipo "histórico-econômica".

O populismo aparece, então, como resultado político de uma industrialização estruturalmente dependente, em uma configuração tal que nenhuma das classes ou setores dominantes, de origem rural ou urbana, é capaz de "deter com exclusividade o poder político", em uma situação de impasse permanente. Essa dinâmica estrutural teria levado ao "jogo populista" e, por meio dele, à crise das "circunstâncias de compromisso" e ao processo no qual o Estado "se 
afasta" de seus "interesses imediatos" para se "sobrepor ao conjunto da sociedade como soberano" (Weffort, 1966, p. 142).

A ideia de o Estado emergir como órgão que se autonomiza em relação às classes, servindo de árbitro em suas disputas, apareceu como resultado da combinação entre a leitura das análises de Furtado sobre o subdesenvolvimento e o contato com os escritos de Karl Marx, especialmente o 18 Brumário, e o conceito de bonapartismo. Weffort tendia, como consequência, a destacar o papel reduzido do momento “ideológico", ou seja, da capacidade de disputa do poder político pelos grupos sociais em contextos de crise, especialmente pelas classes populares.

Em Furtado, a "redução" da política aparecia explicada como produto dos limites da formação capitalista brasileira de passado colonial, na qual o protagonismo político-ideológico seria deslocado para a esfera ética da "responsabilidade dos intelectuais" (Furtado, 1964, pp. 9-10). ${ }^{25}$ Já em Weffort, a ideia do protagonismo ético-político dos grupos intelectuais era convertida no esforço em se desvencilhar do "passado ideológico" da intelectualidade nacionalista por meio da afirmação de uma sociologia da política menos "normativa" e, por isso, mais cientificamente capaz de compreender a autonomização do Estado e o populismo para além da ação dos grupos sociais.

O populismo é apresentado, entáo, como resultado da crise de arbitragem dos conflitos sociais a partir de suas classes dominantes, devido aos "obstáculos estruturais" colocados pelo/ao processo de industrialização e também pela radicalização dos conflitos entre as classes sociais na política brasileira (Weffort, 1966, p. 143 , p. 145, p. 153). O processo que culmina no golpe de 1964, por sua vez, é apresentado como crise de um ciclo de manipulação de "situaçôes de massa" com a emergência do questionamento da própria soberania do Estado (Weffort, 1966, p. 156). Nessa conjuntura de paralisia estatal progressiva, por sua vez, a ideologia seria polarizada entre o mito nacionalista/populista do "Estado democrático de todo o povo" e o mito conservador de um "Estado revolucionário", sendo este último mais bem-sucedido ao reagir ao problema da soberania (Weffort, 1966, p. 157).

Entre meados dos anos 1960 e início dos 1970, o protagonismo dos intelectuais universitários nas análises das crises políticas nos países da América Latina encontrou na Cepal e na circulação de intelectuais no ambiente chileno uma instituição relevante. Este que foi um período, ainda, da emergência do conceito de "dependência" como chave alternativa à do subdesenvolvimento para explicação da inserção subordinada dos países do continente no capitalismo mundial. ${ }^{26} \mathrm{~A}$ produção ao redor da dependência não era uniforme em suas bases teóricas, diagnósticos e conclusōes, de modo que, mais que uma "teoria", talvez o mais adequado seja falar de construçóes analíticas que partiam da noção de dependência. De maneira geral, a "dependência" serviu como léxico compartilhado por intelectuais latino-americanos identificados com o campo democrático - em muitos casos com o socialismo e com correntes marxistas - e que se sentiam desafiados a explicar a realidade histórica, social e política de seus países em termos internacionais e relacionais. ${ }^{27}$

Essa necessidade era especialmente sentida entre os intelectuais brasileiros para os quais a dependência aparecia como aliada da conceituação crítica do populismo. Em meados dos anos 1960, Fernando Henrique Cardoso desenvolveu longa e explicitamente os argumentos de Weffort a respeito do fenômeno do populismo no Brasil para discutir os limites da "presença passiva” das massas populares na política brasileira a partir dos anos 1930 (Cardoso, 1964, pp. 86-91). A "política de massas", afirmou, aparecia em estratos populares que não eram capazes de conformar uma "classe" em sentido político, o que era reforçado pela "rejeiçâo" do populismo como "política retrógrada" pelas vanguardas de esquerda e sindicatos em nome de "uma política ideológica" (Cardoso, 1964, p. 91).

Anos depois, no ensaio sociológico sobre a dependência latino-americana escrito no Chile entre 1967 e 1968, em parceria com Enzo Faletto, Cardoso passaria a considerar o populismo pelo ângulo das transformaçóes nos padrões de acumulação capitalista no continente e dos consequentes rearranjos na estrutura de classes. Em Dependência e desenvolvimento na América Latina (Cardoso e Faletto, 1970), os dois argumentaram que a crise das experiências populistas não seria o resultado da polarização entre dependência e desenvolvimento, polos entre os quais 
se dividiriam burguesia e proletariado, mas significava o processo de redefinição profunda da vida política e econômica dos grupos sociais como um todo. Essa redefinição consistiria na ampliação da penetração dos "interesses externos" no setor de produção para o mercado interno e no nascimento de novas alianças políticas daí resultantes, sustentadas pelo apoio das populaçóes urbanas e dos grupos sociais ligados à produção industrial (Cardoso e Faletto, 1970, pp. 141-142).

Em 1967, período da redação desse ensaio sociológico, a revista francesa Les Temps Modernes publicou um número especial dedicado ao Brasil, sob a coordenação de Celso Furtado, do qual Cardoso e Weffort - também no Chile nessa época, atuando como pesquisador do Ilpes - participaram..$^{28}$ Cardoso (1968) contribuiu com o artigo Hegemonia burguesa e independência econômica: raizes estruturais da crise politica brasileira, no qual aplicou ao caso brasileiro os argumentos centrais de sua pesquisa com Faletto e aprofundou a crítica à ideia de uma burguesia nacional interessada na independência econômica do país.

No artigo de Weffort para esta ediçáo, O populismo na politica brasileira - que viria a compor a coletânea de 1978 como Capítulo III e dar título a ela -, a noção de dependência apareceu já em suas frases iniciais, articulando a definição de populismo (Weffort, 1968a, p. 50). ${ }^{29}$ De maneira análoga a Cardoso e Faletto, Weffort caracterizou o populismo como forma dependente de "incorporação" das massas populares ao Estado no contexto de crise da ordem liberal-oligárquica. O processo de ampliação "pelo alto" da ordem estatal seria possibilitado pela relativa fragilidade dos grupos dominantes urbanos de uma sociedade historicamente "agrária" e "dependente", mas que vislumbrava a possibilidade de construção de um "capitalismo nacional".

Weffort retomou a ideia de que a burguesia industrial - e, de resto, o conjunto dos grupos sociais dominantes, classes médias urbanas, oligarquias regionais e primário-exportadoras - seria incapaz de exercer um papel dirigente à frente do Estado em contextos de crise e transição. Essas seriam situaçôes favoráveis para emergência de uma situação ou Estado "de compromisso", isto é, para a formação de um novo - ainda que precário - equilíbrio entre interesses divergentes que possibilitaria a autonomização relativa do Estado diante das classes sociais e sua personalização na figura do chefe do executivo, o qual passaria a desempenhar o papel de árbitro (Weffort 1968a, p. 63). O compromisso não se referiu, agora, apenas ao papel da liderança populista em uma "situação de massas", mas ao processo de ascensão e crise dessa solução política no Estado.

Em diálogo crítico com o artigo de Ruy Mauro Marini, Contradiçôes e conflitos do Brasil contemporâneo, publicado em 1966 na revista chilena Arauco, Weffort avançou o argumento afirmando que o populismo não poderia ser explicado por analogia à análise marxiana de bonapartismo. Primeiro, devido ao fato de emergir de uma aliança com grupos sociais fundamentalmente urbanos das camadas populares, e não rurais (Weffort 1968a, p. 62) Segundo, dado o caráter dependente desse compromisso populista em relação ao "externo", ou seja, em virtude da especificidade da formação dos países latino-americanos. O caráter periférico e dependente do "compromisso" nos países latinoamericanos, por sua vez, produziria formas de ação política diversificadas que, investigadas propriamente, poderiam contestar a tese da "passividade" ou "falta de ideologia" das classes populares brasileiras (Weffort 1968a, p. 65).

Para explicar a crise do compromisso populista no Brasil do início dos anos 1960, Weffort apontou dois processos concomitantes. $\mathrm{O}$ primeiro se ligava à crise do padrão de dominação política. $\mathrm{O}$ populismo se caracterizaria por uma ascensão, o momento da "manipulação das massas", seguido por uma fase de "mobilização popular" e, finalmente, crise do "compromisso", no contexto em que "a economia urbano-industrial" esgota "sua capacidade de absorção de novos migrantes e quando se restringem as margens do redistributivismo econômico" (Weffort 1968a, p. 70). Isso implicava no segundo processo, de esgotamento do equilíbrio das pressóes produzidas no sentido da ampliação da participação política, período em que a industrialização alcançaria seu limite máximo devido à presença parasitária do setor exportador de produtos primários na situação de compromisso. A estagnação do equilíbrio intraburguês, por sua vez, teria sido fundamental para que a indústria brasileira se tornasse progressivamente mais dependente de capitais externos e, portanto, incapaz de "formular 
uma política" própria para renovar a "manipulação" das massas (Weffort 1968a, p. 70).

Meses depois de escrever o artigo para a revista francesa e já de volta ao Brasil, Weffort retomou a "noção de dependência" em sua tese de doutorado, Classes populares e política: contribuição ao estudo do populismo, defendida em abril de 1968 na USP (Weffort, 1968b, p. 21). ${ }^{30}$ Aqui, a noção de dependência, em seu auge nas ideias do autor, apareceu caracterizando o que pareceria ser uma fase de aproximação empática do autor em relação ao populismo. A dependência foi definida como um conceito que combinaria as premissas da "autonomia política e dependência econômica”, ou seja, definindo a própria condição específica dos países da América Latina, essencialmente ambígua (Weffort, 1968b, p. 21). Na tese, Weffort concentrou-se, então, na fase "mobilizadora" do populismo, ou seja, nas "condiçóes da emergência política das classes populares”, e discutiu as "peculiaridades da formaçáo política e social dependente da América Latina” e seu papel decisivo nos impasses desse processo (Weffort, 1968a, pp. 22-23).

\section{O sindicalismo populista}

No mesmo mês em que Weffort defendeu o doutorado, uma greve radicalizada eclodiu na cidade de Contagem (Minas Gerais), "fora dos marcos do sindicato" com um forte movimento de ocupaçóes e enfrentamentos (Weffort, 1972a, p. 37). A greve se expandiu e, em maio de 1968, grandes revoltas estudantis estouraram no plano internacional, especialmente na França, com grande impacto no "clima ideológico e político" brasileiro, especialmente entre os jovens (Weffort, 1972a, p. 75). "Não eram poucos os que pensavam na possibilidade histórica de uma inversão das relaçóes tradicionais entre estudantes e classe operária”, de uma "nova época dos movimentos sociais", Weffort escreveria mais tarde (Weffort, 1972a, p. 75). Em maio, protestos estudantis radicais eclodiram na França e logo se expandiram para outros países. Em julho, um novo movimento grevista operário emergiu, agora na região de Osasco, em São Paulo, também com fortes ocupaçóes e enfrentamentos.
Esse foi o contexto, também, de fundação de um importante centro intelectual, Cebrap, do qual Weffort se tornou imediatamente pesquisador. Fundado em 1969, como forma de dar continuidade ao trabalho de pesquisa entre intelectuais cassados nas universidades ou perseguidos politicamente pela ditadura em curso, o Cebrap foi fundado originalmente pela sociologia de Florestan Fernandes e pelo marxismo, bem como estabeleceu vínculos importantes com setores da oposição ao regime militar e também com fundaçôes internacionais de financiamento à pesquisa, como a Fundação Ford. Nos anos 1970, esse centro desempenharia um papel de destaque na renovação das interpretações sobre o Brasil, seu lugar no mundo e a transição democrática (Lahuerta, 2001, pp. 60-61, p. 63).

Os protestos e greves de 1968 tiveram grande impacto no ambiente político-cultural brasileiro e, em Weffort, abalaram a já frágil confiança nas virtudes do compromisso dependente populista. Em março de 1971, Weffort apresentou em um "Seminário sobre participação social”, realizado pela International Institute for Labour Studies (OIT-ONU), em Lima, os resultados de uma "pesquisa sobre a história social brasileira” conduzida no Cebrap. Nessa comunicação, Participação e conflito industrial: Contagem e Osasco (1968), descreveu as greves nas duas cidades brasileiras como parte de um "processo de ruptura interna do sindicalismo populista" e emergência da independência operária contrastante com o movimento sindical vigente (Weffort, 1972a, p. 87, grifo adicionado).

O mesmo abalo pode ser sentido também em Notas sobre a 'teoria da dependência': teoria de classe ou ideologia nacional, comunicação apresentada em novembro de 1970 no $2^{\circ}$ Seminario Latinoamericano para el Desarrollo, realizado no Chile sob organização da Faculdad Latinoamericana de Ciencias Sociales (Flacso). ${ }^{31}$ Esse texto seria incluído na coletânea de 1978 sobre o populismo como Capítulo VIII, dividido em dois temas principais: a ambiguidade do conceito de dependência estrutural e a insuficiência do modelo europeu para a história da formação social e política na periferia capitalista. Aqui, Weffort defendeu que a combinaçáo do uso do conceito de dependência e a perspectiva eurocêntrica para explicaçáo do surgimento do Estado-nação levaria necessariamente a uma defesa 
ideológica da perspectiva do subdesenvolvimento, ou seja, nacionalista (Weffort, 1971, pp. 9-10).

Weffort estava preocupado em realizar um deslocamento na discussão da "relação entre classes e nação no desenvolvimento do capitalismo na América Latina" e avançar em uma possível "teoria de classe" na qual a noção de nação não fosse tomada como princípio (Weffort, 1971, p. 6, p. 23). Para tal, propôs repensar "o papel da temática nacional no âmbito das relaçóes políticas e ideológicas entre as classes" (Weffort, 1971, p. 6). A seu ver, as diferentes abordagens sobre a "dependência" na regiáo, inclusive em sua melhor formulação - proposta por Cardoso e Faletto -, seguiam reproduzindo uma "função ideológica" ao defender uma independência nacional possível sem "ruptura concomitante das relaçôes de dominação (internas) de classe" (Ibid., p. 9n).

No comentário que fez ao texto de Weffort, Cardoso admitiu que o debate sobre a dependência havia assumido uma carga ideológica que dificultava uma apreciação equilibrada e matizada das diferentes contribuiçōes (Cardoso, 1971, p. 27). Apesar disso, reiterou que o uso da categoria poderia servir como base para uma crítica do economicismo e o evolucionismo das teorias convencionais do desenvolvimento, especialmente no exame de situaçôes concretas latino-americanas. Para Weffort, contudo, apesar da tentativa de forjar um novo conceito - não apenas um "novo rótulo" para a "velha ideia de país semicolonial" -, as ambiguidades da iniciativa não teriam sido superadas. Por esse motivo, a noção de dependência passava a cumprir uma função "ideológica", ao lado de termos como "nação" e "nacionalismo". Estas seriam, a seu ver, noçóes ultrapassadas analítica e politicamente, por isso "ideológicas" se contrapostas ao desafio de elaboração de uma "teoria" de classe. No caso brasileiro, as greves de 1968 representavam o surgimento de uma consciência "verdadeira" - ou, ao menos, mais original - do processo histórico, em contraste com a consciência "falsa" - ou limitada - dos grupos intelectuais associados ainda ao paradigma "modernizante".

A noçáo de dependência teria o mérito de formular um conjunto de problemas específicos a respeito das relaçóes entre a naçâo e as classes sociais, e sobre as relaçóes de produção no capitalismo latino-americano
(Weffort, 1971, p. 12). Sua ambiguidade, contudo, a impediria de oferecer uma resposta inovadora ao problema do desenvolvimento latino-americano e, assim, de promover uma nova unidade teórico-prática. Uma ambivalência que se mantinha apesar da tentativa de Cardoso e Faletto em apreender, sob a noção de "dependência estrutural", a estrutura de classes e as relaçōes de produção na região. Para Weffort, essa formulação não seria suficiente, pois anulava a dimensão política no estudo das relações sociais nos contextos "dependentes".

Quando comparadas, as diferentes versóes da comunicação de Weffort ${ }^{32}$ permitem supor que, inicialmente, seu autor admitiu usos possíveis da noção de dependência na análise da realidade latino-americana. Na versão publicada no Estudos Cebrap, contudo, Weffort consolidou a rejeição desse léxico teórico (Weffort, 1971, p. 13). Na primeira versão, o texto discutia a capacidade da noção de dependência em operar como "conceito totalizante", equiparável à nação (Weffort, 1971, p. 10 apud Cardoso, 1971, p. 31). O texto questionava a possibilidade de existir "uma questão nacional em geral" e afirmava a necessidade de combinar a dimensão nacional com uma análise política "ao nível supranacional" (Weffort, 1971, p. 8 , p. 15 apud Cardoso, 1971, p. 34n, p. 37). Na versão publicada, o nível supranacional é substituído pelo "nível das relaçôes de produção" (Weffort, 1971, p. 19). Weffort cogitava inicialmente aproveitar o conceito de dependência em uma abordagem mais ampla das classes sociais, em uma teoria "supranacional" do imperialismo. A segunda versão do texto, contudo, revelou um afastamento decisivo do uso do conceito. ${ }^{33}$

No mesmo período, a crítica ao viés economicista das interpretaçóes cepalinas ganharia importante reforço entre os intelectuais brasileiros com a publicação de Mas alla del estancamiento: una discussion sobre el estilo del desarollo reciente del Brasil, por Maria da Conceição Tavares e José Serra, na revista mexicana $E l$ Trimestre Económico. Nesse artigo, publicado na edição de outubro-dezembro de 1971, os dois economistas brasileiros enfrentaram o argumento cepalino da "estagnação estrutural" da economia brasileira nos anos 1960 (cf. Tavares e Serra, 1971/1998). No ano seguinte, em 1972, Francisco de Oliveira publicaria, na Estudos Cebrap, o importante A economia brasileira: 
crítica à razão dualista ${ }^{34} \mathrm{e}$, assim como Tavares $\mathrm{e}$ Serra, apontou o pouco na teoria da dependência da possibilidade, teórica e empírica, de expansão do capitalismo na "periferia" distante do "modelo ocidental" clássico de desenvolvimento capitalista (Oliveira, 1972/2003, p. 33n). ${ }^{35}$

No artigo sobre as greves brasileiras de 1968 , por sua vez, Weffort apresentou a hipótese do dualismo do sindicalismo pré-1964, que se orientava pela estratégia "de aliança com governos" (Weffort, 1972a, p. 7). As mobilizações sindicais de 1968 revelavam esses traços do "sindicalismo populista" (Ibid., p. 27) - em particular com sua tendência em promover processos de aliança e renovação pelo alto - ao mesmo tempo em que era possível identificar pontos de ruptura com essa dinâmica. Estes últimos, na opiniāo de Weffort, indicavam o esgotamento do sindicalismo populista e apontavam para "uma mudança nas bases do sistema [oficial de regulação dos conflitos trabalhistas]" e a formação de "embriōes de organização autônoma pela classe operária” (Ibid., pp. 92-93).

Como visto, em abril de 1978 - exatos dez anos depois da defesa da tese de doutorado sobre o populismo - Weffort publicou a coletânea $O$ populismo na politica brasileira, reunindo para tal textos escritos e publicados entre 1963 e 1971 . Em sua apresentação, anunciou a intenção política do livro: oferecer uma sistematização de ideias potencialmente úteis em um contexto nacional que dava "sinais de um possível ressurgimento das classes populares na política brasileira” (Weffort, 1978a, p. 11). ${ }^{36}$ Além disso, declarou que manteria os textos do período e compartilhava a perspectiva da dependência apesar de não mais concordar com suas premissas. Apesar das modificaçóes introduzidas nesse conjunto de escritos para a nova publicação, o afastamento da abordagem dependentista não é óbvio quando olhamos apenas para os textos escolhidos e revisados. Nestes, a noção de sindicalismo populista não aparece, e tampouco é possível ter dimensão do percurso político-intelectual de Weffort antes da publicação da coletânea, entre 1972 e 1978.

$\mathrm{Na}$ tese de livre-docência defendida em 1972 na USP, Sindicato e politica, (Weffort, 1972b), Weffort abordou o tema "das relaçóes entre sindicatos e a política durante o período que vai de 1945 a 1964" (Weffort 1972b, p. ii). Partindo dos estudos sociológicos de Juarez Rubens Brandão Lopes, José Albertino Rodrigues e Aziz Simão - que procuravam se afastar da perspectiva descritiva e jurídica no tratamento do assunto -, Weffort propôs estudar os sindicatos como parte específica - "corporativa" - de uma "história política” brasileira (Weffort 1972b, p. iii). A ênfase do trabalho recaía sobre os "aspectos políticos" das "atitudes e comportamento da classe operária nas relações de trabalho e nas relaçôes políticas" (Weffort 1972b, p. ii). O "ângulo" político do estudo, justificava, devia-se à percepção de que o sindicalismo brasileiro nos anos 1950 e 1960 teria se transformado em uma espécie peculiar de Leviatá, um "produto 'artificial"” da "vontade dos homens, ou melhor, de alguns homens" (Weffort 1972b, p. iii-iv). A "excepcionalidade" do objeto projetava a política adiante dos "fatores de ordem estrutural". ${ }^{37}$

Pouco tempo depois, Weffort separou o segundo capítulo da tese, sobre o período de 1945-1950, acrescentou uma introdução sistematizando seus argumentos e intitulou o texto Origens do sindicalismo populista no Brasil (a conjuntura do após-guerra). Este foi apresentado oralmente no seminário Movimientos Laborales en América Latina, realizado na Cidade do México em novembro de 1972 e publicado em abril de 1973 na Estudos Cebrap. O artigo deu origem a uma discussão polêmica no interior do Cebrap sobre as relaçóes entre as esquerdas, o sindicalismo e o Estado no pós-guerra, em um contexto de desdobramentos importantes para a trajetória política e intelectual de boa parte dos integrantes do centro. ${ }^{38} \mathrm{O}$ "sindicalismo populista” era para Weffort a categoria-chave da articulação de uma "política de compromisso" não apenas entre as diferentes elites e os indivíduos na massa, mas também entre organizaçôes sociais e o Estado. $\mathrm{O}$ enfoque analítico do populismo era deslocado do fenômeno eleitoral para o estudo do vínculo entre sindicatos, partidos e poder público. Uma elaboração conceitual que teve impacto sobre um conjunto não desprezível de pesquisas que tomaram esse sentido ampliado de populismo como chave analítica de interpretação da conexão entre classes populares organizadas e "poder público" no Brasil (cf. Rowland, 1974; Vianna, 1976; Benevides, 1976; Moisés, 1978; Munhoz, 1978; Martins, 1979; Cohn, 1980). ${ }^{39}$ 


\section{O populismo na política brasileira}

No contexto de publicação de $O$ populismo na politica brasileira, como indicado, Weffort havia chegado a uma interpretação do conceito impossível de ser concebida na ocasião da publicação dos textos até 1971. Essa mudança não aparece claramente anunciada na apresentação da coletânea, mas nas incorporaçóes ao texto de 1963 para publicação como primeiro capítulo da mesma, a nova interpretação transparece na ideia de 1964 como momento de ruptura, de "liquidação de toda a elite política" de então, e pela "exclusão política de quase toda a sociedade civil brasileira" (Weffort, 1978a, p. 17).

Em 1963, a crítica ao nacionalismo se concentrava em sua incapacidade de crítica à ambiguidade que envolvia o fenômeno do populismo, pensado como uma forma efetiva de participação popular democrática. $\mathrm{Na}$ versão de 1978, contudo, Weffort propôs a ideia do populismo como um tipo restritivo de liderança de massas, "uma das principais formas de imobilização política no período democrático" (1978a, p. 24, grifo adicionado). Além disso, destacou o papel apassivante da cultura populista na orientação do conjunto das organizaçóes de esquerda - particularmente o Partido Comunista Brasileiro, bem como os sindicatos e as organizaçóes estudantis.

Ao final dos anos 1970, aliás, o Iseb já passara definitivamente para a margem de seu confronto polêmico, convertido em passado intelectual de uma certa forma de pensar a política para dar lugar à análise do efeito da política "reformista nacionalista" sobre a luta partidária, estudantil e sindical no contexto de uma nova transiçáo democrática. O pensamento político em franco desenvolvimento no Cebrap, por sua vez, de contornos liberal-democráticos, assumia esse lugar e, em seu interior, a reflexão sobre o papel da política comunista na política brasileira.

$\mathrm{Na}$ versão de 1963, Weffort caracterizava o pensamento liberal como o "espírito tradicional", expressão de uma camada social decadente e incapaz de compreender uma democracia com participaçáo das massas. $\mathrm{O}$ nacionalismo, por outro lado, cumpriria papel de "forma dominante de consciência", com sua enorme capacidade de "pressão ideologizante" (Id., 1965a, p. 172). Em 1978, essas ideias aparecem reconsideradas: os liberais são apresentados como "mais lúcidos" que os nacionalistas ao apontar os perigos da associação entre democracia e populismo, apesar de a "hegemonia ideológica" do período ter sufocado essa crítica (Id., 1978a, p. 25).

No início dos anos 1960, Weffort divergiu de Gabriel Cohn, para quem as esquerdas deveriam voltar para o trabalho de "organização em longo prazo" diante da tendência de isolamento e "esvaziamento do significado concreto dessa esquerda na atividade política global" (Cohn, 1965, p. 157). Weffort, então, apostava em "lançar dúvidas" no ambiente populista em crise, no qual lideranças e massas pareciam não falar mais a mesma língua (Pinheiro, 1975, p. 82, p. 160). Quinze anos depois, a ênfase nessa disputa "interna" ao populismo seria discretamente abandonada. Weffort manteve a interpretaçáo de que o populismo representa um compromisso entre elites políticas e massas populares, uma solução diante da incapacidade dirigente das classes dominantes e da fragilidade política das classes subalternas.

A virada analítica de Weffort em relação ao populismo como destino inevitável da política brasileira, iniciada em 1968, acompanhou tendências internacionais de interpretação dos novos ciclos de protestos e organização popular emergentes nos anos 1970. Nessa nova fase, o papel arbitral do Estado cedeu lugar para o estudo do conflito na sociedade civil e das forças que atuam para canalizar e neutralizar institucionalmente as iniciativas de autonomia popular. O populismo não mais pensado como resultado de um compromisso produzido no processo eleitoral, mas como dinâmica ativa e permanente de canalização estatal das energias populares na sociedade civil, tomando como exemplo típico a atividade sindical. ${ }^{40}$ No sindicalismo populista, portanto, a dependência política não é uma condição estrutural prévia, mas uma construção sistemática, para a qual contribuem não apenas por lideranças carismáticas e eleitorais como também organizaçōes políticas atuantes nos conflitos cotidianos entre trabalhadores, empresas e governos.

Nessa fase mais tardia de estudo do populismo, como vimos, Weffort reuniu, revisou, organizou e publicou parte de seus escritos anteriores de maneira combinada à publicação de textos resultantes de uma nova agenda de pesquisa. $\mathrm{O}$ nacionalismo 
democrático, ou populista, foi proposto agora como tradição intelectual e política derrotada historicamente, como ideologia interna a um ciclo de crise das classes dominantes brasileiras, sendo seu papel político o de imobilizar a ação política das massas populares. No lugar, Weffort assinalou o valor das críticas de tipo liberal-democráticas - importância da liberdade de expressão e do pluralismo, da educação política e a desconfiança em relação às formas políticas estatistas. Por meio delas, reconduziu a análise da participação popular no movimento amplo e progressivo de reorganização popular contra a ditadura. Sob essa fórmula, liberal-democrática e popular, o cientista político via emergir uma síntese histórica e política nova, ou o que chamou de "um ponto de vista novo sobre o que pode vir a ser a participaçáo da classe operária em nossa política” (Weffort, 1976, p. 82).

\section{Conclusão}

O objetivo deste artigo foi reconstruir a contribuição específica de Francisco Weffort aos estudos sobre o populismo no Brasil. Para tal, lançou mão da restituição das versões originais de seus artigos sobre esse tema, bem como da reconstrução cronológica e intelectual da escrita e publicação dos mesmos. Nesse processo, muitas camadas analíticas de sobrepuseram: o estudo do ambiente editorial (as revistas políticas e os periódicos acadêmicos em circulação) e intelectual (particularmente, aqui, dos centros de pesquisa, estatais ou não); a formação de uma linguagem de análise política específica, acadêmica e com intençóes científicas, em sincronia não apenas com a conformação da ciência política brasileira, mas também do sistema de pós-graduação brasileiro.

Nesse emaranhado político-intelectual, os escritos de Weffort sobre o populismo também são parte da história da relação dos grupos intelectuais brasileiros com as lutas populares e a democracia. $\mathrm{O}$ objetivo do presente artigo, nesse sentido, não foi realizar o julgamento do autor, mas tecer no passado a trama de dilemas que permanecem atuais, tanto para o fazer acadêmico como o fazer político dos cientistas sociais. São as perguntas, e não as respostas, que justificam a caminhada.

\section{Notas}

1 Ver, por exemplo, os importantes trabalhos de Jorge Ferreira (2001), Daniel Aarão Reis Filho (2001) e Angela de Castro Gomes (1988/2005). A ausência do recurso à reconstrução cronológica e textual das versōes dos textos de Weffort que compóem a coletânea $O$ populismo na politica brasileira não invalida o mérito desses trabalhos, evidentemente. $O$ presente artigo visa a enriquecer este terreno político-intelectual brasileiro já estabelecido, levantando temas e problemas ainda pouco explorados e que podem se beneficiar das pesquisas em história do pensamento político para tal.

2 Para as primeiras versóes apresentadas e publicadas da presente pesquisa ver Mussi e Kaysel (2017a; 2017b; 2017c). Ver, também, Szwako e Araujo (2019) em um artigo recente que parte de achados desta para uma tentativa de história intelectual do populismo.

3 Instituiçáo vinculada à Comissão Econômica para a América Latina (Cepal).

4 Filologia, aqui, refere-se ao método de seleção e leitura dos documentos reunidos no corpus do trabalho (cf. McGann, 2013). A pesquisa filológica é distinta de uma "história das ideias" tradicional, pois reconhece o terreno do pensamento político como fraturado e, por esse motivo, desconfia dos processos de validaçáo retrospectivos de conceitos e teorias. A eficácia das ferramentas filológicas, no presente trabalho, deve-se ao fato de que estas legitimam o estudo e a conexão de documentos com base em dois princípios básicos: a valorização de textos originais; e o retorno sistemático a essas fontes primárias (McGann, 2013, p. 341). Para o estudo da filologia como método de trabalho, ver Erich Auerbach (1969). Para uma perspectiva filológica crítica, ou seja, pensada como ética de leitura que náo nega o texto como algo interno a relaçóes de força e conflito, ver Edward Said (1978; 1983).

5 O Iseb nasceu como think tank vinculado ao Ministério da Educação brasileiro e funcionou entre 1955 e 1964. Para a história e o papel político do Iseb, ver Toledo (1997; 2005), para uma interpretação do papel da perspectiva desenvolvimentista no Iseb, ver Sérgio Wanderley (2016).

6 De acordo com Ferreira (2013, p. 117), as "esquerdas" dessa época eram diminutas e normalmente aparecem nas análises como sinônimo de Partido Comunista (PCB), sua dissidência Partido Comunista do Brasil (PCdoB), a Organização Revolucionária MarxistaPolítica Operária (ORM-Polop), a Ação Popular - dois agrupamentos com forte presença no movimento estudantil - e o pequeno grupo "posadista" Partido Revolucionário Trotskista (POR-T). Estas figuram 
como as importantes nas pesquisas, embora Ferreira argumente que outros partidos, movimentos sindicais e populares eram bastante ativos neste período, embora não apareçam comumente incorporados nas análises do processo que culminou no golpe. Para as esquerdas da época, ver também o trabalho de Marcelo Ridenti (1993).

7 Para datação, ver a apresentação de Weffort (1978a, p. 11) à coletânea $O$ populismo na política brasileira, que abre com o referido texto.

8 Esta passagem seria excluída da versão do texto publicado em 1978. No seu lugar, Weffort inseriu um longo parágrafo sobre o golpe de 1964 reforçando uma leitura mais pessimista do fenômeno: "As massas populares não fizeram a 'baderna' temida pela direita nem saíram em defesa do governo Goulart como esperavam as lideranças reformistas. Em abril de 1964 elas foram ainda mais uma vez o parceiro-fantasma do jogo político: em seu nome o reformismo e o governo formulavam sua política de reforma agrária e nacionalizaçóes [...]" (Weffort, 1978a, p. 16).

9 Não foram poucos os intelectuais e grupos políticos brasileiros que leram, no calor dos acontecimentos, a crise da renúncia de Quadros como abertura de um momento revolucionário no Brasil. Ver, por exemplo, o estudo de Jorge Ferreira (2013) sobre as análises do PCB dessa época; ver, também, Florestan Fernandes (1976).

10 Para uma interpretação clássica da debilidade organizativa e pouca representatividade dos partidos naquele período, ver Maria do Carmo Campelo de Souza (1976). Para uma leitura que relativiza essa debilidade observando a ação estratégica dos partidos diante das mudanças nas regras eleitorais em 1945, ver Limongi (2012).

11 Na versão de 1978, a passagem é reformulada: "a liderança de massas de tipo populista, que se constituiu em uma das principais formas de imobilização política no período democrático, e o nacionalismo, ideologia que inspirou as linhas básicas da ação de diversas organizações de esquerda (principalmente o PC) e teve grande influência sobre os sindicatos e associaçóes estudantis" (Weffort, 1978a, p. 24, grifos no original). O principal destaque, nesta mudança, está na caracterização definitiva do populismo como "forma de imobilização política" em 1978 , em contraste com a ideia de "raiz do poder real", do Estado, presente no original de 1963.

12 De acordo com Jorge Ferreira, as primeiras referências ao populismo no Brasil podem ser encontradas em artigos da imprensa liberal que estigmatizavam negativamente os adeptos do "queremismo" em 1945 (cf. Ferreira, 2001).
13 O ensaio "Que é o adhemarismo?", de Jaguaribe, publicado na revista do Ibesp (posteriormente, Iseb) Cadernos do Nosso Tempo: revista de cultura e informação política, em 1954, é considerado o primeiro a utilizar o termo "populismo" nas ciências sociais brasileiras (Gomes, 2001). Em entrevista ao programa 1964, da Univesp TV, realizada em 31 de março de 2014, Weffort afirmou que o uso do termo "populismo" se deu justamente como referência ao slogan "aliança populista", usado por Adhemar de Barros para se referir à campanha comum com Getúlio Vargas nas eleiçóes de 1950 (cf. Teixeira, 2014).

14 Sobre o adhemarismo e janismo, ver Regina Sampaio (1982) e John French (1987).

15 A interpretação de Weffort se distinguia também daquela oferecida por Victor Nunes Leal na tese de doutorado que deu origem a Coronelismo, enxada e voto, publicado em 1948. Analisando a política municipal no Brasil, Leal desenvolvera a hipótese do coronelismo como categoria explicativa da combinação entre "formas desenvolvidas do regime representativo" e "uma estrutura econômica e social inadequada” (Leal, 2012, p. 23). Weffort já nessa época pensa o populismo como uma forma política plenamente moderna, e não referente apenas à política rural.

16 Termo que, na coletânea de 1978, aparece substituído por "hegemonia" (Weffort, 1978a, p. 25).

17 Para uma interpretação distinta da política do PCB nos anos que antecederam o golpe de 1964, ver Jorge Ferreira (2013).

18 Na versão de 1978, essa definição apareceria com a seguinte redação: "O populismo é, no essencial, a exaltação do poder público; é o próprio Estado colocando-se através do líder, em contato direto com os indivíduos reunidos na massa" (Weffort, 1978a, p. 28, grifo adicionado). A mudança é interessante e indica que, desde 1963, o objetivo de Weffort era indicar o populismo como uma forma de mediação, de canalização de um conflito em um sentido institucional. $\mathrm{O}$ centro da definição era a função conectiva cumprida pelo líder populista entre Estado/poder público e os indivíduos na massa.

19 A $R C B$ circulou entre 1965-1968 e tinha um caráter de revista cultural, feita para aglutinar os intelectuais e publicar, nas palavras do editor Ênio Silveira, temas que pudessem interessar, ao mesmo tempo, "ao ambiente político e universitário" (Ênio Silveira em entrevista ao sociólogo Luiz Renato Vieira, em 22 maio 1992 in VIEIRA, Luiz Renato. (1998), Consagrados e malditos: os intelectuais e a editora Civilização Brasileira. Brasília, Thesaurus apud Galucio, 2009, p. 131). Apesar de filocomunista, a $R C B$ não representava as ideias do $P C B$, mas publicava artigos que endereçavam de maneira 
ampla as principais discussōes realizadas no partido no contexto pós-golpe. Para uma pesquisa extensiva sobre a $R C B$, ver Andréa Galucio (2009).

20 A pesquisa consistia na aplicação de questionários, respondidos por 200 eleitores dos bairros de alta penetração populista em São Paulo, complementados por dados referentes à votação de Adhemar e Jânio naquele ano. $\mathrm{Na}$ introdução do relatório, redigido em 1963, consciente da limitação empírica da pesquisa, o texto afirma que procederia a análise por meio da construçáo de tipos-ideais, embora preservando uma perspectiva totalizante, numa clara tentativa de combinar a metodologia de Weber com a de Marx, consistente com o tipo de trabalho intelectual desenvolvido no âmbito da sociologia uspiana nesse período (Weffort, 1965b, pp. 40-41; para a datação do manuscrito, cf. Weffort, 1966, p. 149n).

21 Para a política de Jânio Quadros, ver Maria Victoria de Mesquita Benevides (1989) e Vera Chaia (1991).

22 Na versão de 1978, esta passagem foi modificada. $\mathrm{Na}$ nova versão ficou: "que conduz inevitavelmente, através do desenvolvimento capitalista, ao esmagamento da pequena burguesia pelos grandes capitais" (Weffort, 1978a, p. 34). Ver adiante.

23 A referência de Weffort neste texto ao "populismo nacionalista" remete ao discurso de posse de Miguel Arraes no governo de Pernambuco em 1963 (Arraes, 1979).

24 A dataçáo precisa da redação foi estabelecida com base em algumas marcas filológicas. $\mathrm{Na}$ coletânea de 1978, Weffort afirma apenas que o texto "é de 1964" (Weffort, 1978a, p. 12). Em uma nota de rodapé de "Estado e massas no Brasil", o autor se refere ao artigo "Raízes sociais do populismo em São Paulo" como "manuscrito" de 1963, o que faz concluir que a redação de "Estado e massas no Brasil" foi concluída antes da publicaçấo daquele. Isso permite estabelecer como marco temporal final da redaçáo o mês de maio de 1965. "Estado e massas", além disso, cita o livro de Fernando Henrique Cardoso, Empresário industrial e desenvolvimento econômico, publicado em abril de 1964, o que permite estabelecer neste mês o marco temporal inicial. Estas consideraçôes permitem sugerir, ainda, que a redação deste artigo se deu em período sobreposto e/ou imediatamente posterior ao da revisão final do capítulo "Política de massas" para a coletânea Política e revolução social no Brasil (Weffort, 1966, p. 149, 10n; 1978a, p. 12).

25 Reflexão presente também nas anotações de Roberto Schwarz (1978) desse período sobre os limites da hegemonia dos grupos de esquerda.

26 Excertos de algumas das principais obras produzidas em torno da controvérsia da dependência estão compilados em
Marini \& Millán (1994). Para um amplo levantamento bibliográfico, inclusive com trabalhos produzidos em outros continentes, ver Dos Santos (1998).

27 Para um mapeamento dos debates entre cepalinos e dependentistas, ver Love (1996). Já para diferentes critérios de organizaçẫo da controvérsia da dependência, ver Dos Santos (2000). Por fim, para uma apreciaçáo crítica do lugar das "teorias da dependência" no marxismo latino-americano, ver Portantiero (1990).

28 Edição traduzida integralmente para o português e publicada na forma de livro em 1968, versão usada no presente artigo.

29 " $[\mathrm{O}$ populismo] manifesta também a fragilidade política dos grupos urbanos dominantes quando procuram substituir a oligarquia nos postos de comando de um país tradicionalmente agrário e dependente [...]" (Weffort, 1968a, p. 50).

30 A partir da tese, Weffort comporia boa parte da Segunda Parte da coletânea de 1978: o Capítulo I da Primeira Parte seria convertido em Capítulos IV e V; o Capítulo IV da Terceira Parte seria convertido em Capítulo VI; o Capítulo V da Terceira Parte seria convertido em Capítulo VII (cf. Weffort, 1968b; 1978a). Para a nova composição, Weffort alterou alguns dos títulos dos capítulos e revisou parcialmente o texto, eliminando principalmente o termo "dependência".

31 Texto comentado por Fernando H. Cardoso que, para tal, escreveu "Teoria da dependência ou análises concretas de situaçôes de dependência?" Os textos do debate foram publicados em versóes modificadas no ano seguinte no boletim Estudos Cebrap. A intervenção de Weffort foi publicada, ainda, na Revista Latinoamericana de Ciência Politica, n. 1,em 1971.

32 Passagens transcritas por Cardoso na versão publicada do comentário à comunicação de Weffort apontando justamente a diferença entre a versão apresentada e aquela publicada (cf. Cardoso, 1971).

33 Para uma crítica da oposição, por Weffort, entre as noçóes de classe, por um lado, povo e nação, por outro, ver Kaysel (2018, pp. 64-67, pp. 74-84).

34 Texto em que Weffort também aparece citado em nota introdutória de agradecimentos (Oliveira, 1972/2003, p. 27, p. 61).

35 Em uma nota de rodapé na introdução desse ensaio, Oliveira escreveu: "Este ensaio foi escrito como uma tentativa de resposta às indagaçóes de caráter interdisciplinar que se formulam ao Cebrap, acerca do processo de expansão sócio-econômica do capitalismo no Brasil."

36 Referência às primeiras movimentaçōes sindicais na região do $\mathrm{ABC}$ paulista que, em poucas semanas, expandiu-se enormemente, conformando um ciclo de 
greves operárias que só se encerraria no ano seguinte (cf. Antunes, 1992; Santana, 2007).

37 Além da Introdução, a tese foi dividida em quatro capítulos. O primeiro dedicado à comparar o populismo no Brasil e na Argentina no período anterior à 1945; o segundo voltado a uma primeira tentativa, "fracassada", de formação do sindicalismo populista entre 1945-1950; o terceiro para discutir a "renovação" do populismo e a emergência do sindicalismo populista entre 1950-1954; e o último a respeito dos "sindicatos na política" no contexto que antecedeu o golpe civil-militar de 1964 .

38 Uma discussão que tinha, em seu centro, o balanço ação do PCB na conjuntura política e sindical que antecedeu o golpe de 1964, a respeito da qual Weffort se tornara bastante crítico. "Origens do sindicalismo populista..." foi seguido de uma réplica por Carlos Estevam Martins e Maria Hermínia Tavares de Almeida, "Modus In Rebus" (cf. Martins e Almeida, 1973). Weffort escreveria uma tréplica, "Dejémonos de farsas inútiles" (cf. Weffort, 1974?). O autor ainda voltaria à polêmica em um texto sem data, "Partidos, sindicatos e democracia: algumas questóes para a história do período 1945-1964" (Id., s/d) e, por fim, a revisão e publicação deste, entre 1978 e 1979, como artigo dividido em três partes nas revistas do recém-fundado Centro de Estudos e Cultura Contemporânea (Cedec) (cf. Weffort, 1978b, 1979a, 1979b). Parte desse conjunto de escritos permaneceu inédita. Para uma discussão pormenorizada destes, ver Vianna (1977, p. 80ss) e Mussi e Kaysel (2017b).

39 Para uma crítica posterior do "modelo interpretativo" de Weffort a respeito da percepção popular do populismo, tomando como base a coletânea de 1978, ver Duarte e Fontes (2004).

40 Ver Luiz Werneck Vianna (1977, p. 78) para uma discussáo da contribuiçáo inovadora de Weffort para os estudos sindicais.

\section{BIBLIOGRAFIA}

ANTUNES, Ricardo. (1992), A rebeldia do trabalho (o confronto operário no ABC Paulista: as greves de 1978-1980). São Paulo, Unicamp.

ARRAES, Miguel. (1979), "Discurso de posse" [pronunciado perante a Assembleia Legislativa de Pernambuco, em 31 jan. 1963] in Guita Debert. Ideologia e Populismo. São Paulo, T. A. Queiroz.

AUERBACH, Eric. (1969), "Philology and Weltliteratur". The Centennial Review, 13, 1: 1-17.

BARIANI JUNIOR, Edison. (2003), Sociologia no Brasil: uma batalha, duas trajetórias (Florestan
Fernandes e Guerreiro Ramos). Dissertação de mestrado. Araraquara, Faculdade de Ciências e Letras, Universidade Estadual Paulista Júlio de Mesquita Filho.

BENEVIDES, Maria Victoria de Mesquita. (1976), O governo Kubitschek: desenvolvimento econômico e estabilidade política. Rio de Janeiro, Paz e Terra.

BENEVIDES, Maria Victoria de Mesquita. (1989), Governo Jânio Quadros. São Paulo, Brasiliense.

CARDOSO, Fernando Henrique. (1964), Empresário industrial e desenvolvimento econômico. São Paulo, Companhia Editora Nacional.

CARDOSO, Fernando Henrique. (1968), "Hegemonia burguesa e independência econômica: raízes estruturais da crise política brasileira”, in Celso Furtado (org.). Brasil: tempos modernos. Rio de Janeiro, Paz e Terra.

CARDOSO, Fernando Henrique. (1971), “Teoria da dependência ou análises concretas de situaçóes de dependência?”. Estudos Cebrap, 1.

CARDOSO, Fernando Henrique; FALETTO, Enzo. (1970), Dependência e desenvolvimento na América Latina. Rio de Janeiro, Jorge Zahar.

CHAIA, Vera Lucia Michalany. (1991), A liderança política de Jânio Quadros: 1947 a 1990. São Paulo, Humanidades.

COHN, Amélia. (1980), Previdência social e processo político no Brasil. São Paulo, Moderna.

COHN, Gabriel. (1965), "Perspectivas da esquerda”, in Gabriel Cohn; Octavio Ianni; Paul Singer (orgs.). Política e revoluçâo social no Brasil. Rio de Janeiro, Civilização Brasileira.

COMITÊ CENTRAL DO PCB. ([1958] 1982), "Declaração sobre a política do PCB". Voz Operária, 22 mar., in Edgard Carone. O PCB (1943-1964). São Paulo, Difel.

DOS SANTOS, Teotônio. (1998), "Por uma bibliografia da Teoria da Dependência”. Revista Estudos Avançados, 12, 33.

DOS SANTOS, Teotônio. (2000), A teoria da dependência: balanco e perspectivas. Rio de Janeiro, Civilização Brasileira.

DUARTE, Adriano; FONTES, Paulo. (2004), "O populismo visto da periferia: adhemarismo e janismo nos bairros da Mooca e São Miguel 
Paulista (1947-1953)”. Cadernos AEL: populismo e trabalhismo. Unicamp/IFCH/AEL, 11, 20/21.

FERNANDES, Florestan. (1976), A sociologia numa era de revolução social. Rio de Janeiro, Zahar.

FERREIRA, Jorge. (2001), "O nome e a coisa: o populismo na política brasileira" in Jorge Ferreira (org.). O populismo e sua história: debate e crítica. Rio de Janeiro, Civilização Brasileira.

FERREIRA, Jorge. (2013), "O Partido Comunista Brasileiro e o governo João Goulart”. Rev. Bras. Hist., São Paulo, 33, 66: 113-134.

FRENCH, John. (1987), “A ascensão do populismo adhemarista em São Paulo - 1946/1947”. Série de textos sobre história eleitoral - Idesp, 19.

FURTADO, Celso. (1964), Dialética do desenvolvimento. Rio de Janeiro, Fundo de Cultura.

GALUCIO, Andréa Lemos Xavier (2009), Civilização Brasileira e Brasiliense: trajetórias editoriais, empresários e militância política. Tese de doutorado. Rio de Janeiro, Programa de Pós-Graduação em História, Universidade Federal Fluminense.

GOMES, Angela Castro. ([1988] 2005), A invenção do trabalhismo. Rio de Janeiro, FGV Editora.

GOMES, Angela Castro. (2001), O populismo nas Ciências Sociais brasileiras, in FERREIRA, Jorge (org.). O populismo e sua história: debate e crítica. Rio de Janeiro, Civilização Brasileira.

IANNI, Octavio. (1965), "Processo político e desenvolvimento econômico", in Gabriel Cohn; Octavio Ianni; Paul Singer (orgs.). Politica e revoluçáo social no Brasil. Rio de Janeiro, Civilização Brasileira.

JAGUARIBE, Hélio. (1954), "Que é o adhemarismo?” Cadernos do Nosso Tempo, (2).

KAYSEL, André. (2018), Entre a nação e a revolução: marxismo e nacionalismo no Peru e no Brasil (1928-1964). São Paulo, Alameda.

LAHUERTA, Milton. (2001), "Intelectuais e resistência democrática: vida acadêmica, marxismo e política no Brasil". Cadernos AEL, VIII, 14-15: 55-94.

LEAL, Victor Nunes. (2012), Coronelismo, enxada e voto: o municipio e o regime representativo no Brasil. Rio de Janeiro, Companhia das Letras.
LIMONGI, Fernando. (2012), "Eleições e democracia no Brasil: Victor Nunes Leal e a transição de 1945". Dados, 55, 1: 37-69.

LOVE, Joseph L. (1996), "Economic ideas and ideologies in Latin America since 1930”, in Leslie Bethell (ed.). Ideas and ideologies in Twentieth Century Latin América. Cambridge, Cambridge University Press.

MARINI, Ruy Mauro \& MILLÁN, Márgara (orgs.). (1994), Teoría Social Latinoamericana, v. 2. México D. F., UNAM.

MARTINS, Carlos Estevam; ALMEIDA, Maria Hermínia Tavares de. (1973), Modus in Rebus: partidos e sindicatos na queda do Estado Novo. São Paulo, Mimeo.

MARTINS, Heloísa de Sousa. (1979), Estado e burocratização do sindicato no Brasil. São Paulo, Ática.

MCGANN, Jerome. (2013), "Philology in a New Key”. Critical Inquiry, 39 (2), pp. 327-346. Disponível em: www.journals.uchicago.edu/ doi/10.1086/668528; consultado em: 21 out. 2019.

MOISÉS, José Álvaro. (1978), Greve de massa e crise política (estudo da greve dos 300 mil em São Paulo 1953-1954). São Paulo, Pólis.

MUNHOZ, Fabio A. (1978), "Sindicalismo e democracia populista: a greve de 1957”. Cadernos Cedec, 2.

MUSSI, Daniela; KAYSEL, André. (2017a), "Populismo, classe e nação: Francisco Weffort e a teoria da dependência (1967-1972)". Anais do $9^{\circ}$ Congresso Latino-Americano de Ciência Politica, Montevidéu.

MUSSI, Daniela; KAYSEL, André. (2017b), "Populismo, sindicalismo e democracia: a polêmica entre Francisco Weffort, Carlos Estevão Martins e Maria Hermínia Tavares de Almeida”. Anais do $41^{\circ}$ Encontro Anual da Anpocs. Caxambu.

MUSSI, Daniela; KAYSEL, André. (2017c), “Da política de massas às massas na política: $F$. Weffort e o populismo no Brasil". Seminário de Pós-Graduação do Departamento de Ciência Politica (USP). São Paulo. 
OLIVEIRA, Francisco de. ([1972] 2003), Crítica à razão dualista. O ornitorrinco. São Paulo, Boitempo.

PINHEIRO, Paulo Sérgio. (1975), Política e trabalho no Brasil. Rio de Janeiro, Paz e Terra.

PORTANTIERO, Juan Carlos. (1990), “O marxismo latino-americano", in Eric Hobsbawm (org.). História do marxismo, v. 11. Rio de Janeiro, Paz e Terra.

RAMOS, Alberto Guerreiro. (1961), A crise do poder no Brasil. Rio de Janeiro, Jorge Zahar.

REIS FILHO, Daniel Aarão. (2001), "O colapso do colapso do populismo", in Jorge Ferreira. $O$ populismo e sua história: debate e crítica. Rio de Janeiro, Civilização Brasileira.

RIDENTI, Marcelo. (1993), O fantasma da revolução brasileira. São Paulo, Editora Unesp.

RODRIGUES, Lidiane Soares. (2012), A produção social do marxismo universitário em Sáo Paulo: mestres, discipulos e "um seminário"(1958-1978). Tese de doutorado em História Social. São Paulo, Faculdade de Filosofia, Letras e Ciências Humanas, Universidade de São Paulo.

ROMÃO, Wagner de Melo. (2006), Sociologia e política acadêmica nos anos 1960: a experiência do Cesit. São Paulo, Humanitas.

ROWLAND, Robert. (1974), "Classe operária e Estado de compromisso (origens estruturais da legislação trabalhistas e sindicais)". Estudos Cebrap, 8.

SAID, Edward. (1978), Orientalism. Nova York, Vintage Books.

SAID, Edward. (1983), "The World, the Text and the Critic", in Edward Said. The World, the Text and the Critic. Cambridge, Harvard Press.

SAMPAIO, Regina. (1982), Adhemar de Barros e o PSP. São Paulo, Global Editora.

SANTANA, Marco Aurélio. (2007), "Trabalhadores em movimento: o sindicalismo brasileiro nos anos 1980-1990", in Jorge Ferreira; Lucilia Delgado (orgs.). Brasil Republicano, v. 4. Rio de Janeiro, Civilização Brasileira.

SCHWARZ, Roberto. (1978), O pai de família e outros estudos. Rio de Janeiro, Paz e Terra.
SCHWARZ, Roberto. (1999), "Um seminário de Marx”, in Roberto Schwarz. Sequências brasileiras. São Paulo, Companhia das Letras.

SEGATTO, José Antonio. (1995), Reforma e revolução: as vicissitudes politicas do PCB (1954-1964). Rio de Janeiro, Civilização Brasileira.

SOUZA, Maria do Carmo Campello de. (1976), Estado e partidos politicos no Brasil (1930-1945). São Paulo, Alfa-ômega.

SZWAKO, José; ARAUJO, Ramon. (2019), "Quando novos conceitos entraram em cena: história intelectual do populismo e sua gênese no debate brasileiro sobre movimentos sociais". Estud. hist. (Rio J.), Rio de Janeiro, 32, 67: 469499. Disponível em: http://dx.doi.org/10.1590/ s2178-14942019000200008; consultado em: 16 jan. 2020.

TAVARES, Maria da Conceição \& SERRA, José. ([1971] 1998), "Mas lla del estancamiento: una discussion sobre el estilo del desarollo reciente del Brasil", El Trimeste Económico, 33, 152, in Cincuenta años de pensamiento en la Cepal: textos seleccionados. México D.F., Fondo de Cultura Económica, v. II.

TEIXEIRA, Mônica. (2014), 1964: entrevistas | Francisco Weffort [vídeo]. São Paulo (SP): Univesp TV. Disponível em: www.youtube. com/watch?v=slX2EYgpPGQ; consultado em: 17 fev. 2020.

TOLEDO, Caio Navarro (org.). (2005), Intelectuais e politica no Brasil: a experiência do Iseb. Rio de Janeiro, Revan.

TOLEDO, Caio Navarro. (1997), Iseb: fábrica de ideologias. Campinas, Unicamp.

TOLEDO, Caio Navarro. (2004), "1964: o golpe contra as reformas e a democracia”. Rev. Bras. Hist., 24, 47: 13-28.

VIANNA, Luiz Werneck. (1976), Liberalismo e sindicato no Brasil. Rio de Janeiro, Paz e Terra.

VIANNA, Luiz Werneck. (1977), "Estudos sobre sindicalismo e movimento operário: resenha de algumas tendências". Boletim de Informação Bibliográfica, 3: 69-93.

VIANNA, Luiz Werneck. (1994), "Cientistas sociais e vida pública (Introdução)”. Dados, 37, 3: 357-403. 
WANDERLEY, Sergio. (2016), "Iseb, uma escola de governo: desenvolvimentismo e a formação de técnicos e dirigentes”. Adm. Pública, 6, 50: 913-936.

WEFFORT, Francisco. (1965a), "Política e massas", in Gabriel Cohn; Octavio Ianni; Paul Singer (orgs.). Política e revolução social no Brasil. Rio de Janeiro, Civilização Brasileira.

WEFFORT, Francisco. (1965b), "Raízes sociais do populismo em São Paulo”. Revista Civilização Brasileira, 1, 2: 39-60.

WEFFORT, Francisco. (1966), "Estado e massas no Brasil”. Revista Civilização Brasileira, 1, 7: 137-158.

WEFFORT, Francisco. (1968a), "O populismo na política brasileira”, in Celso Furtado (org.). Brasil: tempos modernos. Rio de Janeiro, Paz e Terra.

WEFFORT, Francisco. (1968b), Classes populares e política: contribuição do estudo do populismo. Tese de doutorado. São Paulo, Faculdade de Filosofia, Ciências e Letras, Universidade de São Paulo.

WEFFORT, Francisco. (1971), "Notas sobre a 'teoria da dependência': teoria de classe ou ideologia nacional". Estudos Cebrap, 1: 1-24.

WEFFORT, Francisco. (1972a), "Participação e conflito industrial: Contagem e Osasco (1968)". Cadernos Cebrap, 5.

WEFFORT, Francisco. (1972b), Sindicato e politica. Tese de livre-docência. São Paulo, Faculdade de
Filosofia, Letras e Ciências Humanas, Universidade de São Paulo.

WEFFORT, Francisco. (1973), "Origens do sindicalismo populista no Brasil (a conjuntura do após guerra)”. Estudos Cebrap, 4.

WEFFORT, Francisco. (1974?), Dejémonos de farsas inutiles! História crítica ou história ideológica? São Paulo, Mimeo.

WEFFORT, Francisco. (1976), "Do anarquismo ao populismo (entrevista)". Cadernos de Debate, 1: 77-80.

WEFFORT, Francisco. (1978a), O populismo na politica brasileira. Rio de Janeiro, Paz e Terra.

WEFFORT, Francisco. (1978b), "Democracia e movimento operário: algumas questôes para a história do período 1945-1964 (primeira parte)”. Revista de Cultura Contemporânea, 1, 1: 7-13.

WEFFORT, Francisco. (1979a) "Democracia e movimento operário: algumas questóes para a história do período 1945-1964 (segunda parte)". Revista de Cultura Contemporânea, 1, 2: 3-11.

WEFFORT, Francisco. (1979b), "Democracia e movimento operário: algumas questóes para a história do período 1945-1964 (terceira parte)". Revista de Cultura Politica, 1, 1: 11-18.

WEFFORT, Francisco. (s/d), Partidos, sindicatos e democracia: algumas questóes para a história do período 1945-1964. São Paulo, Mimeo. 


\section{OS POPULISMOS DE FRANCISCO WEFFORT}

\author{
Daniela Mussi and André Kaysel \\ Velasco e Cruz
}

Palavras-chave: Francisco Weffort; Populismo; Pensamento político brasileiro; História do pensamento político; Filologia

O presente artigo investiga o pensamento de Francisco Weffort por meio da reconstruçáo da coletânea $O$ populismo na politica brasileira, publicada em 1978, mas composta por textos do período 1963-1971. Usando recursos filológicos, o trabalho discute os escritos do autor reunidos para publicação do livro, contextualizando-os e comparando suas diferentes versôes. Por meio da reconstrução dos momentos de escrita do autor, caracteriza os ambientes intelectuais e políticos no qual este se insere, bem como suas diferentes reflexôes a respeito do populismo. Explora, em seguida, os escritos do período 1972-1978 sobre o tema, mas não inseridos na coletânea estudada. $\mathrm{O}$ artigo propóe que: a) na coletânea de 1978 estáo presentes ao menos dois sentidos do conceito de populismo, anteriores a 1971; b) consequentemente, a coletânea $O$ populismo na politica brasileira não contempla uma definição homogênea ou finalizada do conceito, já que exclui o conceito de sindicalismo populista com o qual Weffort trabalhou ao longo de toda a década de 1970. Por fim, conclui que, para uma crítica rigorosa do conceito de populismo em Weffort, é importante levar em conta uma leitura cronologicamente rigorosa da coletânea, bem como dos textos deste período deixados de fora da mesma.

\section{THE POPULISMS OF FRANCISCO WEFFORT}

\author{
Daniela Mussi and André Kaysel \\ Velasco e Cruz
}

Keywords: Francisco Weffort; Populism; Brazilian political thought; History of Political Thought; Philology

This article investigates Francisco Weffort's thinking through the reconstruction of the Populism in Brazilian Politics collection, published in 1978 , but comprising texts from 1963 to 1971 . Using philological techniques, the study discusses the author's writings gathered for the book publication, contextualizing and comparing them in their different versions. By reconstructing the author's writing moments, the article characterizes his intellectual and political environments, as well as his different populism interpretations over time. It then explores writings on the subject from 1972 to 1978 which were not included in the assessed collection. The article proposes that: a) at least two senses concerning the populism concept prior to 1971 are present in the 1978 collection and that b) consequently, Populism in Brazilian politics does not contemplate a homogeneous or finalized definition of the concept, as it excludes the populist unionism concept that Weffort worked with throughout the 1970s. Finally, it concludes that, in order to carry out a rigorous critique of the populism concept noted in Weffort, it is important to take into account a rigorously chronological reading of the collection, as well as of other texts from this period left out of this collection.

\section{LES POPULISMES DE FRANCISCO WEFFORT}

\author{
Daniela Mussi et André Kaysel Velasco \\ e Cruz
}

Mots-clés: Francisco Weffort; populisme; pensée politique brésilienne; histoire de la pensée politique; philologie.

Le présent article analyse la pensée de Francisco Weffort à partir d'une reconstitution du recueil $O$ populismo na politica brasileira, publié en 1978 mais composé de textes rédigés entre 1963 et 1971 . Se valant de ressources philologiques, le travail examine les écrits réunis pour la publication, les replace dans leur contexte et compare les différentes versions. Il resitue les moments d'écriture de l'auteur dans les environnements politiques et intellectuels de l'époque et met l'accent sur ses réflexions autour du populisme. Dans un deuxième temps, l'article étudie les écrits de la période 1972-1978 sur le même thème mais qui n’ont pas été insérés dans le recueil. Il en ressort que: a) dans le recueil de textes de 1978, au moins deux sens du concept de populisme, antérieurs à 1971, sont présents; b) par voie de conséquence, le recueil ne contient pas une définition homogène ou finalisée du concept vu qu'il ignore le concept de syndicalisme populiste - une notion sur laquelle a travaillé l'auteur tout au long de la décennie 1970. Enfin, pour une critique du concept de populisme chez Weffort, il est important de procéder à une lecture chronologiquement rigoureuse $\mathrm{du}$ recueil et aux textes de la même période qui n'en font pas partie. 